\title{
Continuous multi-criteria methods for crop and soil conservation planning on La Colacha (Río Cuarto, Province of Córdoba, Argentina)
}

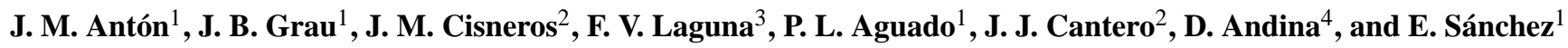 \\ ${ }^{1}$ E.T.S. de Ing. Agrónomos, U.P.M., Av. Complutense 3, Madrid 28040, Spain \\ ${ }^{2}$ Facultad de Ing. Agronomía y Veterinaria, U.N. de Río Cuarto, Pr. de Córdoba, Argentina \\ ${ }^{3}$ E.T.S. de Ing. de Caminos, Canales y Puertos, U.P.M., Ciudad Universitaria, 28040 Madrid, Spain \\ ${ }^{4}$ E.T.S. de Ing. de Telecomunicaciones, U.P.M., Ciudad Universitaria, 28040 Madrid, Spain
}

Correspondence to: J. M. Antón (josemanuel.anton@upm.es)

Received: 28 November 2011 - Revised: 7 May 2012 - Accepted: 20 May 2012 - Published: 13 August 2012

\begin{abstract}
Agro-areas of Arroyos Menores (La Colacha) west and south of Río Cuarto (Prov. of Córdoba, Argentina) basins are very fertile but have high soil loses. Extreme rain events, inundations and other severe erosions forming gullies demand urgently actions in this area to avoid soil degradation and erosion supporting good levels of agro production. The authors first improved hydrologic data on La Colacha, evaluated the systems of soil uses and actions that could be recommended considering the relevant aspects of the study area and applied decision support systems (DSS) with mathematic tools for planning of defences and uses of soils in these areas. These were conducted here using multi-criteria models, in multi-criteria decision making (MCDM); first of discrete MCDM to chose among global types of use of soils, and then of continuous MCDM to evaluate and optimize combined actions, including repartition of soil use and the necessary levels of works for soil conservation and for hydraulic management to conserve against erosion these basins. Relatively global solutions for La Colacha area have been defined and were optimised by Linear Programming in Goal Programming forms that are presented as Weighted or Lexicographic Goal Programming and as Compromise Programming. The decision methods used are described, indicating algorithms used, and examples for some representative scenarios on $\mathrm{La}$ Colacha area are given.
\end{abstract}

\section{Introduction}

The study area La Colacha (Fig. 1) is a $423 \mathrm{~km}^{2}$ tree-shaped configuration of basins, which is a gentle sub-basin of Arroyos Menores, an agro-area $\left(6753 \mathrm{~km}^{2}\right)$ in a marginal Pampean northern region south of Province of Córdoba, which is in the centre of Argentina. Arroyos Menores agro-area is special because it contains ramified basins, as the other east areas of Córdoba plains have more flat lands with larger rivers. La Colacha area corresponds to La Colacha-Cipión streams, confluent towards Santa Catalina stream, as is indicated in Fig. 1 with indications for sub-basins, drainage network and gullies. It has heights from 1000 to $560 \mathrm{~m}$ over sea level, and relief from smooth terrain east to rolling mountainous parts west with $16 \%$ of total surface near an exterior vertical step of mountains west. For hydraulic planning the authors considered La Colacha divided into 167 small sub basins.

The soils of Arroyos Menores are mostly of loess origin from dust brought by wind from the Andes, and they are of texture sandy loam to loam, types very common in $\mathrm{Ar}$ gentina. They are called Typic and mainly Entic Haplustolls, Typic and Cumulic Argiudolls in lower parts, with Entisols over old Spills, and Typic Ustipsamments and Entic Hapludolls (belonging to Mollisols) at SW points of Arroyos Menores over old dunes, and are considered in the "Universidad Nacional Rio Cuarto, UNCR" map from Cantero et al. (1986). Climate is sub-humid with monsoon winds with a dry season (June to September), and for La Colacha with annual average temperature of $16^{\circ} \mathrm{C}$ (range -10 to $42^{\circ} \mathrm{C}$ ), and $80 \%$ of the $860 \mathrm{~mm} \mathrm{yr}^{-1}$ rain occurring between end of 
September-November and March-April, with wet monsoon period including the Southern Hemisphere summer. The soils of Arroyos Menores are very fertile but suffer much from water erosions from wet monsoons, and especially by regressive erosion creating gullies, named here in Spanish cárcavas, through them.

In La Colacha sub basin there are 87 active gullies, indicated roughly in Fig. 1, some with more than $3000 \mathrm{~m}$ length, sometimes increasing $500 \mathrm{~m}$ in one year. There is also hillslope erosion (sensu Wilkinson et al., 2009) and high-bank or meander erosion in rivers showing poor geomorphic conditions (Brierkley and Fryirs, 2005). To restrain these erosions there are plans in Arroyos Menores for hydraulic management (HM), combining binding canals with cover, control of active heads, forestation of basis of gullies, and buffer bands of about $14 \mathrm{~m}$ wide.

The study area has undergone major soil-use and management changes in recent years, moving away from mixed crop and livestock production systems to more agriculturally intensive uses (Degioanni, 2000), with an increasing proportion of soybean (Glycine max) in the crop rotation that is easily exported at international prices, territorial concentration, exclusion of small farmers and employment loss in the rural sector (Pengue, 2005). The combination of soybeans and glyphosate to eliminate other plants allows lack of tillage, tending to reduce erosion risks; but undesirable plants may evolve resistance against glyphosate. The degradation of soils in these regions has been considered, such as by Zack et al. (2008); Paruelo (2011). The basin run-off and sediment export are responsible for negative effects or "externalities" that include sedimentation and the rise of the water table in lowland flood plains as well as flooding and damage to urban and road infrastructure. Other degradation processes in the basin include the loss of biodiversity in the mountains due to overgrazing, fire and non-native species, and episodic wind erosion events in agricultural soils. Inundations of lands, roads and villages occur also in lower areas. Hence the dangers of spoiling these delicate soils with loess have increased, and that makes the related studies and planning important to maintain them in good state.

The La Colacha area has been cultivated for $150 \mathrm{yr}$, but with these relatively recent uses of land, soil has become eroded in part with regressive gullies not more than 10 or $15 \mathrm{~m}$ deep but destroying the flat surfaces and creating barriers that can severely spoil the area in the next 50 to $100 \mathrm{yr}$. Soil conservation (SC) dispositions and HM of the streams, also facilitating irrigation, can prevent or decrease the spoilage. But to be efficient, planning, funds, management and conservation combining public and private agents are required. The effect on soils depends also on the use of soils for agriculture, which has also economic and social effects, and all require private or public actions, in not simple policies to be defined by planning studies. The combined possible actions and effects open a panorama of DSS (decision support systems) that were studied by the authors.
In these DSS considerations, the election of such "policies" or actions is studied by considering their separate effects on diverse natural or human venues. These policies need funding, and when they render diverse products that are sold, these are economic effects. They also have effects on the environment, including soils, erosion, nature occupying it, and these will be called environmental effects. The ways to operate lands require considering different schemes of jobs, has effects on employment and on social patterns, and these are social effects. These diverse effects conduced the authors intending DSS towards MCDM (multi-criteria decision-making) formats, where "policies" became "alternatives" and "effect fields" became "criteria". The presence of diverse future scenarios with probabilities to be elicited was not felt important and hence the Bayesian or MAUT methods were not followed. The application of these MCDM enlarged the expert comprehension of what can be achieved with what sets of consequences.

The elaboration of rules usable for real management required the use of continuous MCDM for La Colacha area, considering delicate combined sets of solutions with varied consequences. This required construction of what will be called "C-models" indicating, with a selected set of continuous variables, the possible elections for areas for different crops and numbers of works for HM and measures for SC as decision variables. Diverse restrictions were imposed by reality or to avoid major troubles, and consequences were evaluated from decision variables for a set of criteria. With the continuous MCDM, various ways of pointing to adequate solutions were tried in goal programming (GP) forms. The authors were inspired to use several of these forms, following diverse possible trends for decisions which correspond to the reality of planning in the presence of private interests and public regulation and investment.

The authors had formerly produced information about the study areas as in Cisneros et al. (2008a, 2011). A revision was made in the literature about systems for planning in similar areas, involving findings for agriculture impact in Europe (Rossing et al., 2007) and for general effects (Millennium Ecosystem Assessment, 2005). Examples of methods are the soil and water assessment tool SWAT (Ullrich and Volk, 2009) and agricultural policy-environmental extender APEX (Gassman et al., 2009) for impact assessments at the basin scale. For water evaluation and planning, WEAP (McIntyre and Wheater, 2004) and MULINO (Giupponi et al., 2004) are examples of integrated MCDM tools. In Kenyon et al. (2008) there is a multi-scale approach from parcel to basin for flood management. In Bryan and Crossman (2008), with a Geographic Information System (GIS) and spatial multi-criteria analyses for efficient local management action they maximise environmental benefits and minimize economic costs. A MCDM is discrete if a reduced number of alternatives are considered, and it is continuous if the values of some real variables defining the solution are calculated. These methods have been 


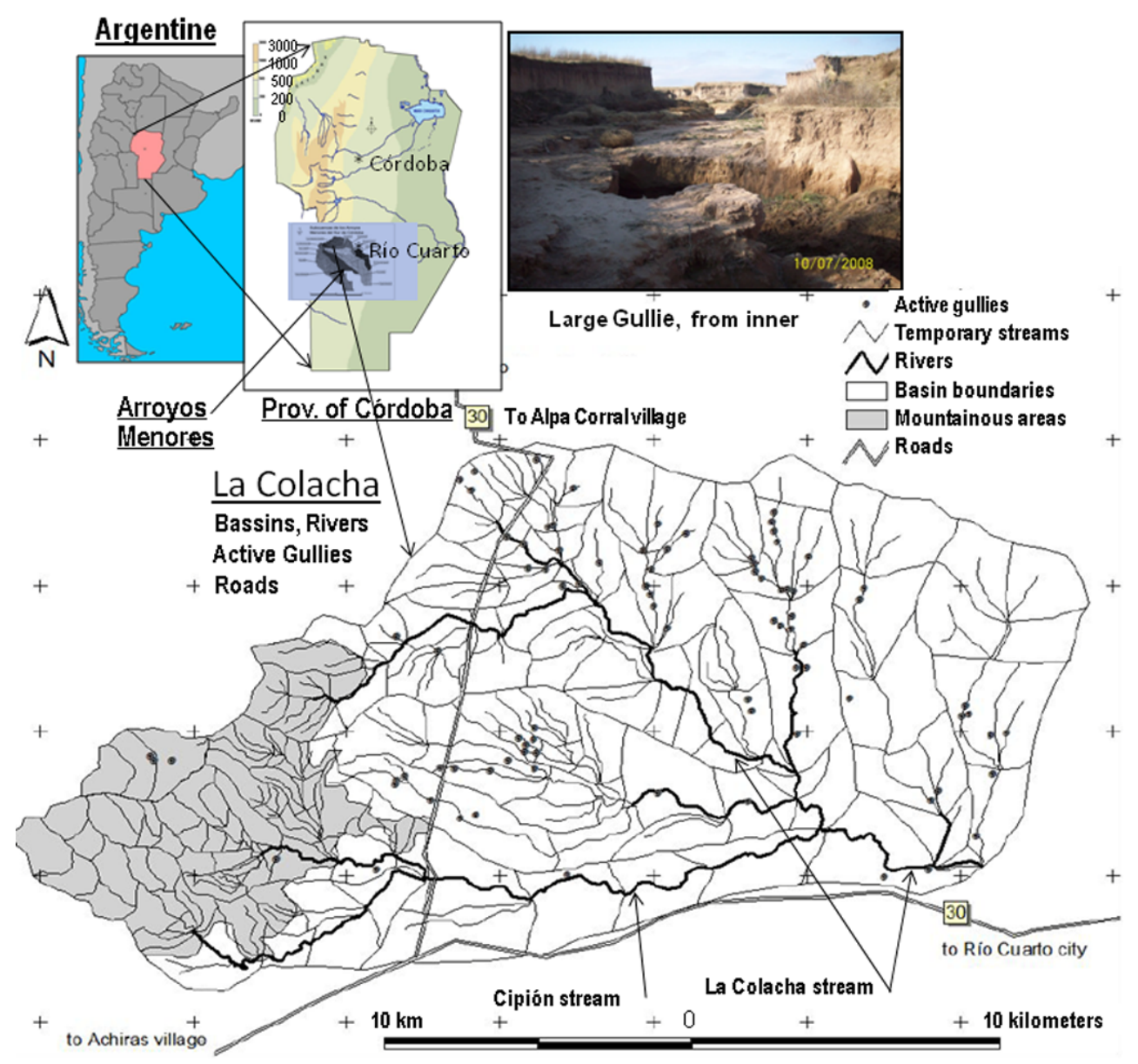

Fig. 1. Location of study area "La Colacha" in Argentine Republic. The altitude map is from "Mapas Visiting", much reduced. Includes a view of basins, rivers, active gullies, roads. A north/south chain of old mountains lies west of study areas.

used in modern agricultural applications for optimising landuse strategies with multiple objectives (Agrell et al., 2004; Hengsdijk and van Ittersum, 2002; Nidumolu et al., 2007), for reservoir management (Chang et al., 1995), for trade-off analyses between agriculture, erosion and non-point-source pollution (Lakhsminarayan et al., 1995), for the optimisation of crop distributions (Groot et al., 2007; Gonçalvez et al., 2007), for flood control problems (Simonovic and Akter, 2006) and for incentives for the application of river buffer strips (Borin et al., 2010). They are scarcer for Latin American developing countries and for the Pampean Region; however several authors have searched for best alternatives of soil use with discrete multi-criteria for distinct regions of Chaco Salteño (Grau, 2003; Anton, 2006; Anton et al., 2010; Grau et al., 2007, 2008, 2009, 2010). Several works can be found on rural areas and roads (de Prada et al., 1994), local effects and policies (Cantero et al., 1998; de Prada and Penna, 2009), MCDM for small watershed (Zhen et al., 2007; Paneque Salgado et al., 2006), planning in agro-areas (Smith and McDonald, 1998) and for various objectives in agricultural policies
(Lakshminarayan et al., 1995). The conservation of soils in Argentina is backed by law (Law 8359, Arg., for conservation of soils), but action is voluntary and scarce (Cristeche, 2009).

The considered general uses of soils were:

1. Agro-silva-pastoral use (ASP): combination of established forests, farming or pasture, depending on the capability of soils; in the mountain parts by rationalised forests and pastures (Udawatta et al., 2002). It is good for environmental and social criteria but at a serious economic cost.

2. Actual use (ACT): based on actual censed use (Cisneros et al., 2008a, b), considered with MCDM methods as in (Janssen, 2001). This includes traditional tillage or lands for pasture, following much the natural conditions. The crops are mainly alternations with cereals and soybean in large plots, in general without irrigation. With that, climate tillage is often not necessary every year in flat lands. Cattle raising is mostly in extensive livestock with agro-complements, e.g. with alfalfa. 
3. Intensive use (INT): more intensive cropping (Cisneros et al., 2005; Manuel-Navarrete et al., 2005). Tillage is normal here; irrigation is set if convenient. For cattle in Argentina there is actually tendency to feedlots where cattle is highly concentrated and nourished with balanced mixtures of maize, soybean and supplements; systems of waste recycling are necessary, needing external control. This use scenario is worse for environmental considerations or criteria.

In these studies the considered crop area ranged from 52 to $87 \%$, the pasture from 13 to $28 \%$ and forest (alley pasture) from 1 to $20 \%$. The crop ratios for soybean to corn ranged from 1:1 to 4:1. The first option was environmentally friendly, and the second represented an agricultural soybeanbased intensification based on the current tendency in the Pampean region, using genetic modified soybean without tillage and eliminating previously undesirable plants with glyphosate. All these studies emphasised the necessity of:

1. Soils Conservation (SC): special measures for plots to prevent erosion, including horizontal tillage, and more specifically (for example) fifty to sixty-meter horizontal interval-graded terraces or pasture buffer strips selected due to their simplicity, economy and regional adaptability testing. They include binding canals with cover, control of active heads, forestation of basis of gullies, and buffer bands of about $14 \mathrm{~m}$ wide. As examples, regulation ponds (micro-reservoirs) or constructed wetlands (Lasage, 2007) consisting of earth dam $3 \mathrm{~m}$ high with base-spillway discharge for peak runoff reduction, gully control by head-cut, point of active retrograde advance (Poesen et al., 2003), maybe by expensive concrete structural spillways or by bioengineering techniques (e.g., Morgan and Rickson, 1995), and gullyfloor control.

2. Hydrological Management (HM): evolving basin-scale technical frameworks designed to reduce peak runoff, increase base flow, reduce sediment (and pollutant) discharge, control gully head-cuts and floor erosion, and stabilise the drainage network. This includes protection of streams, permanent or transitory, and rehabilitation of wetlands, mostly by micro-dams. Eight types of microdams have been designed. At greater scale, dams of some size and descents are to be protected from erosion; some already are. As examples, buffer/filter grass and forest riparian strips for permanent streams called "three-zone strip" (per Lovell and Sullivan, (2006), with grass strip bordering an agricultural zone sized with an "VFSMOD" model, intermediate cultivated forest strip and a variable-width native forest strip close to river bed) to reduce meander erosion. Another technique is grassed waterways as in Fiener and Auerswald (2006) sized for a peak runoff (estimated using "HEC-HMS") covering temporal streams in the basin $(180.3 \mathrm{~km}$ in length). Figure 2 contains a global map indicating hydraulic arrangements recommended by authors for La Colacha basin area.

The HM and SC were found rather necessary to control the spoiling of the lands by erosions that otherwise would spoil them long term, although they are rather non economic at short or middle term. These previous studies produced general indications. Therefore a more precise tuning of solutions for La Colacha, mostly of ACT kind, but of ASP kind in the mountainous west part marked at Fig. 1, and with degrees for HM and SC, was studied with continuous MCDM and is described as follows.

\section{Application of continuous multi-criteria methods for La Colacha sub area}

\subsection{Continuous MCDM used, decision variables set, criteria, C or P-solutions}

The authors have completed for La Colacha area a series of essays with continuous MCDM, emulating mostly Romero and Rehman (1989), Romero (1991, 1993). They indicate these methods as Goal Programming (GP), doctrine that uses constrained optimisation to consider adequately the reality and included multi-criteria, thus belonging to continuous MCDM, which is used also in industrial or economic fields. A condensed exposition of the methods employed will be presented, indicating formulae of optimisation, an election of variables and constraints, and a few results. Weighted Goal Programming (WGP) and Lexicographic Goal Programming (LGP) were considered, and Compromise Programming (CP) using Linear Programming (LP) forms will be presented. To include them for GP, La Colacha planning problem was set as follows.

\section{Solution definition for GP methods}

\section{C-solution}

A complete set of policies and actions for the La Colacha region is considered a solution. Some solutions containing similar actions but differently located will be equivalent, and a set of such equivalent solutions will be indicated by the values of a set of decision variables (DV) $x_{i}$, each one global for the region, chosen to indicate the level of uses of soils and the intensity of measures in SM and HM for the whole region in a global way but enough detailed to determine the global effects for the region. The forest part in the area west of study site and with higher slopes in mountains will not be considered with the criteria variables $(\mathrm{CV})$.

The effects of such a C-solution will be detected through the values of a well chosen comprehensive set of $\mathrm{CV} v b_{j}$, which will be a function of the DV by a set of technical equations (TE) proposed by the authors. 


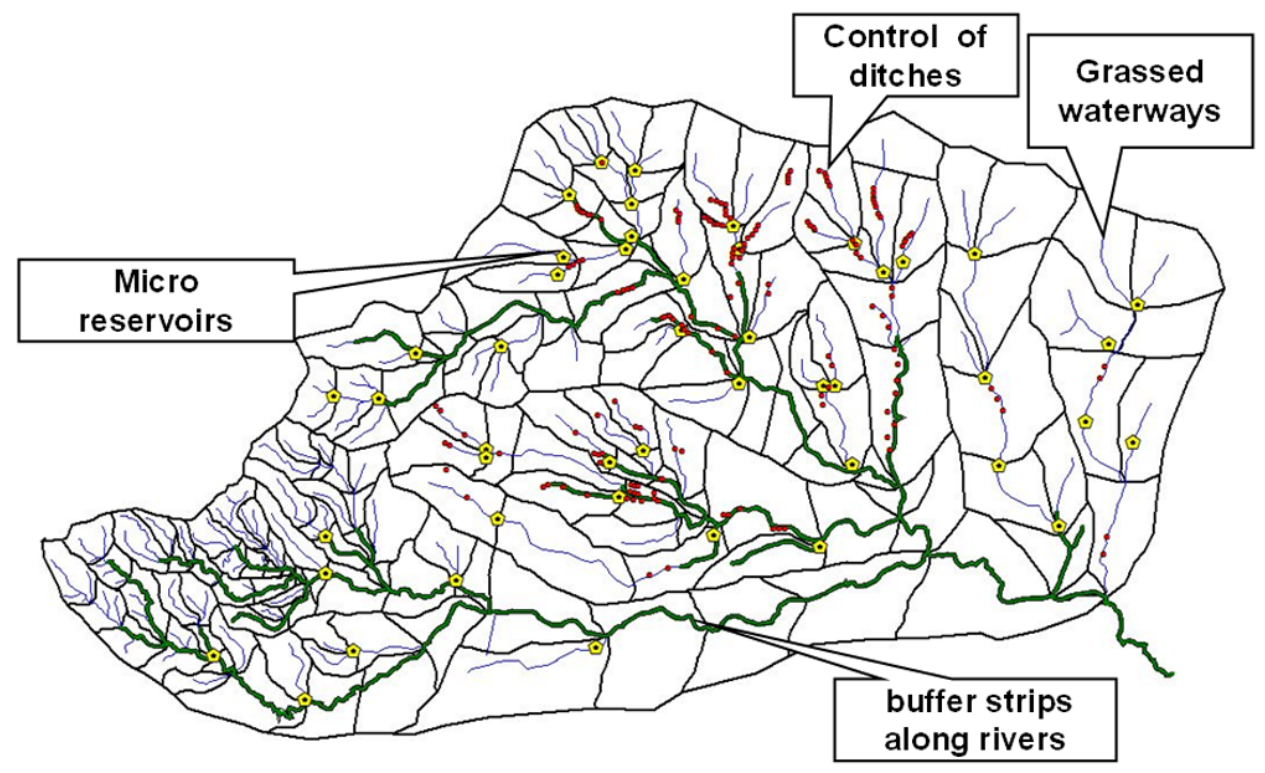

Fig. 2. Proposal of Hydraulic arrangements for La Colacha basin. WM (water management), mainly to control erosions.

\section{P-solution}

Such a set of DV will indicate C-solutions that can be effectuated by actions on the region if the values of the DV are compatible, and if they are so, such set will define what will be called a P-solution. For this a set of technical constraints, TC on the DV will be elicited, containing the conditions that will have to be satisfied by the DV to be compatible, these TC being sufficient if all are fulfilled.

With GP methods optimising with LP, optimum Psolutions can be defined for defined scenarios of chosen GP methods, as will follow with some examples, obtained using a version of LINGO@ optimisation software to get the values of the DV and the CV using LP with real variables or continuous, most of them "non negative". With LINGO, nonlinear equations could be used and integer or logical variables could be imposed.

\section{General LP form for the GP used}

For WGP form, it is exposed in (1) as a LP optimisation determining decision variables (DV) $x_{i}$ defining a P-solution through minimizing an adequate sum for (1a) of weighted relative $j$-deviations $\left(p_{j}, n_{j}\right)$, defined by $(1 \mathrm{~b})$ for "nonnegative $\left(p_{j}, n_{j}\right)$ ), of the $\mathrm{CV} v b_{j}$ from some known $j$-goals $g b_{j}$, the values $v b_{j}$ being defined linearly by TE in (1c) from the $x_{i}$. In the sum for (1a), the $j$-deviations are normalised by dividing by positive $v b_{j}$, taken often as $r b_{j}=g b_{j}$, getting independence on units (that would be a problem if $p_{j}$ is taken). The $j$-deviations are weighted in (1a) with some positive weights $w_{j}$ and $w_{j}^{\prime}$, that in cases will be $w_{j}=0$ or $w_{j}^{\prime}=0$.

This general WGP form contains variables in general "non negative", and will maybe include constraints TC in (1d).

$\left\{\begin{array}{ll}\operatorname{Min}_{x_{i}, v b_{j}, n_{j}, p_{j}}\left(\sum_{j} \frac{\left(n_{j} \cdot w_{j}^{\prime}+p_{j} \cdot w_{j}\right)}{r b_{j}}\right) & \text { (1a) } \\ \text { for each } j, v b_{j}+n_{j}-p_{j}=g b_{j} & \text { (1b) } \\ \text { for each } j, v b_{j}=\sum_{i}\left(a_{i j} \cdot x_{i}\right), \text { as TE, } & \text { (1c) } \\ \text { with TC } \Sigma_{i}\left(a_{i k}^{\prime} \cdot x_{i}\right)\left(\leq \text { or } \geq \text { or }=c_{k}\right) . \text { (1d) }\end{array}\right\}$

In such WGP forms some of the positive or negative $p_{j}$ deviations from the $j$-goals $g b_{j}$ are authorised but penalised to follow the real situation. A $j$-criterion is evaluated by its $\mathrm{CV} v b_{j}$, and it may be of kind "more is better", and then its goal $g b_{j}$ will be generally relatively great. Then the "non negative" measure $n_{j}$ of the unfavourable negative deviation of its $g b_{j}$ from its goal appearing in (1b) will be minimized as indicated in (1a). In these cases, the corresponding positive deviation $p_{j}$ will likely be favourable and will not be minimized, setting in general for it $w_{j}=0$, and will be 0 likely due to the high value of the corresponding $g b_{j}$. And inversely, if a $j$-criteria measured by its $\mathrm{CV} v b_{j}$ is of kind "more is worse", then its goal $g b_{j}$ will be relatively small, and the positive favourable deviation $p_{j}$ of its $v b_{j}$ from it will be minimized with (1a). Then the corresponding $n_{j}$ will likely be favourable and not minimized, setting in general for it $w_{j}^{\prime}=0$, and it will be 0 likely due to the low value of its $g b_{j}$. This occurs in general for the CV and GP methods used in this paper. However other cases may occur, e.g. a $j$-goal 
could be sensible for both senses and both deviations $\left(p_{j}\right.$, $n_{j}$ ) would have to be minimized with (1a), especially when the GP methods are applied in other fields of research.

\section{Decision variables set (DVS)}

To define C-solutions for La Colacha sub-area the authors designed the following DVS of DV $x_{i}$ for $(i=1, \ldots, 13)$, hence with $m=13$. They indicate numerically the use of soil and the level of the SC and HM with some level of precision, but to define a valid C-solution they will have to follow the TC defined later. This adopted DVS is:

A. Corn without the SC area (ha), status quo soil management condition, $x_{1}$,

B. Corn with the SC area (ha), $x_{2}$,

C. Soybean without the SC area (ha), status quo soil management condition, $x_{3}$,

D. Soybean with the SC area (ha), $x_{4}$,

E. Pasture for cattle production area (ha), $x_{5}$,

F. Pasture for buffer strip area (ha), $x_{6}$,

G. Pasture for grassed waterway area (ha), $x_{7}$,

H. Forest-grazing mixed area (agro-forestry use, ha), $x_{8}$,

I. Forest riparian buffer area (ha), $x_{9}$,

J. Forest to gully floor erosion control area (ha), $x_{10}$,

K. Regulation ponds $\left(\mathrm{N}^{\circ}\right), x_{11}$,

L. Active gully head-cut $\left(\mathrm{N}^{\circ}\right)$, that is, non-controlled, $x_{12}$,

M. Controlled gully head-cut $\left(\mathrm{N}^{\circ}\right), x_{13}$.

\section{Criteria variables set (CVS)}

Such a C-solution for La Colacha will be qualified for decisions, in a situation of multi-criteria type, by a CVS set of $\mathrm{CV} v b_{j}$, with $(j=1, . ., 6)$, hence with $n=6$, as follows:

1. Peak run-off (PRU), $v b_{1}=$ peak runoff in $\left[1 \mathrm{~s}^{-1} \cdot \mathrm{ha}^{-1}\right]$, and in $\left[1 \mathrm{~s}^{-1}\right.$ unit $\left.^{-1}\right]$ to regulation ponds, negative if average reduction of peak run-off, favourable.

2. Erosion (ERO), $v b_{2}=$ annual erosion in $\left[\mathrm{Mgha}^{-1}\right]$ or $\left[\mathrm{Mg} \mathrm{unit}^{-1}\right]$ for gullies; a negative sign in the controlled gully category indicates a reduction in the erosion produced by each head-cut control work.

3. Sediment production (SED), $v b_{3}=$ sediment production $\left[\mathrm{Mg} \mathrm{ha}^{-1}\right]$; a negative sign indicates that the works retain sediment and prevent it from reaching a river, or in the controlled gully category a reduction in the sediment production. There is no SED retention in a pond because in designs the disposition of spillway is at the lowest point of the dam structure.

4. Investment (INV), $v b_{4}=$ investment in US $\$ \mathrm{y}^{-1}$, (y) being for "year".

5. Benefit (BEN), $v b_{5}=$ annual benefit in gross margin (US $\left.\$ \mathrm{y}^{-1}\right)$.

6. Employment (EMP), $v b_{6}=$ employment generation (number of jobs).

Due to their nature, the PRU, ERO, SED and INV criteria are of kind "more is worse" and are to be optimised towards their minima, whereas the BEN and EMP criteria are of kind "more is better" and are to be optimised towards their maxima.

\subsection{Technical Equations and Technical Constraints (TC) proposed for La Colacha}

\section{Technical equations matrix (TE)}

$\mathrm{CV}$ are function, as said, of the DV by technical Eq. (1c), $v b_{j}=\sum_{i}\left(a_{i j} \cdot x_{i}\right)$, where the $a_{i j}$ are the elements $\mathbf{T E}_{i j}$ of a TE matrix. The authors have elicited for case studies the matrix TE, adopting decision variables and evaluation criteria as they are in Table 1 to represent the impacts for Csolutions of each DV $x_{i}$ on each CV $v b_{j}$, in fact for valid ones that are P-solutions. For this we have adapted models of processes used in their ampler research, in part from hydrologic and soil science methods and others. For PRU a model HEC-HMS (USACE, 2009) was used to estimate it, and for ERO a model RUSLE 2 (USDA-ARS, 2009), with aids for gullies such as with Dabney et al. (2008). For SED they used estimations MUSLE (Williams, 1975), and for deposits in filter strips following Muñoz-Carpena and Parsons (2005). INV 
was, for cost of possible actuations estimated for La Colacha area, transformed in annuity in standard ways, not differentiating between public and private sources; when it has been obtained for a project from the cost for his lifetime, opportunity interest rate under Argentine conditions was taken as $12 \%$. For BEN, they used about margin in a typical exploitation (de Prada et al., 2008). The crop-weighted gross margin and the cost values were considered at 2010 prices. Monoculture may increment BEN and degrade more soil, but it influences farmers' decisions (Groot et al., 2007; Gil et al., 2008). EMP was estimated following Llach et al. (2004), depending on type of activity and on the yields of the crops. The effects of SC, crop rotation and hydrological management on the PRU, ERO and SED were significant. Forest, pond and gully control costs were important components of the INV. $\mathrm{SC}$ affected BEN, causing a $5 \%$ increase in crop production, which improved the water economy, and forestry had a strong effect on employment.

\section{Technical Constraints (TC)}

As said, to get a valid P-solution the adopted DV and the CV of a C-solution will have to also satisfy TC equations as for (1d) of the GP form in (1). The authors have proposed the following set of TC.

First the DV will be limited as:

a. PRU constraint, $v b_{1}$ : The peak runoff must be less than $4770001 \cdot \mathrm{s}^{-1}$; the maximum value was simulated for the more intensive soil-use scenario, methods in Cisneros et al. (2011). This is a value that reflects a basin condition of maximum degradation or hydrological destabilisation. $v b_{1} \leq 477000$.

b. ERO constraint, $v b_{2}$ : The annual erosion cannot be over $232542 \mathrm{Mg}$, corresponding to the erosion estimate for $90 \%$ soybean soil cover without SC (over 34246 ha of agricultural soils) for a $1.5 \%$ slope condition; from the authors, methods resumed in Cisneros et al. (2011). $v b_{2} \leq 232542$.

c. SED constraint, $v b_{3}$ : For a similar condition of soil use, the maximum sediment delivered was about $48000 \mathrm{Mg} \mathrm{y}^{-1} . v b_{3} \leq 48000$.

d. INV constraint, $v b_{4}$ : The maximum value was estimated by the authors at US $\$ 1000000$, corresponding to completely developed work schemes (SC and HM with ASP). In fact, this means that there was no investment restriction. This value was established in order to explore the minimum investment required to optimise the solutions obtained by the various MCDM tested.

$v b_{4} \leq 1000000$. e. BEN constraint, $v b_{5}$ : This constraint represented the minimum benefit that a farmer was willing to achieve, as observed in situ by the authors, equivalent to land rental (in 2009 average values, US $\$ 172 \mathrm{ha}^{-1}$ ); the value for the entire basin agricultural area was US \$ 5883287 . $v b_{5} \geq 5883287$.

f. EMP number constraint, $v b_{6}$ : The employment could not be less than the actual value, estimated as 382 jobs. $v b_{6} \geq 382$. This is a judgement from authors, interpreting local sentiment.

Moreover the DV will satisfy the 12 constraints that follow, the first of them is the limit for the sum of areas:

g. Agricultural land area constraint, $k=7$. The total area under different soil-use regimes could not be greater than the agricultural land availability (34246 ha). This results in: $x_{1}+x_{2}+x_{3}+x_{4}+x_{5}+x_{6}+x_{7}+x_{8}+x_{9}+x_{10}+$ $109 \cdot x_{11}+2 \cdot x_{12}+0.4 \cdot x_{13} \leq 34246$.

The other 11 constraints contain rational limitations expressed from the "expert knowledge from authors", which detected constraints necessary for the validity of a Csolution:

h. Number of regulation ponds constraint, $k=8$. Fortyseven was the maximum number of ponds simulated, which was a function of the topographically suitable sites in the basin. $x_{11} \leq 47$.

i. Gully number constraint sum, $k=9$. Eighty-seven gullies were registered in the basin; accordingly, no solution greater than this number was logical. $x_{12}+x_{13} \leq 87$.

j. Grassed waterways area constraint, $k=10$. The maximum area measured with grassed channels was 344 ha, corresponding to the soil-intensive use peak runoff. $x_{7} \leq 344$.

k. Grass buffer strip area constraint, $k=11$. The maximum required buffer area to reduce sediment charge by $75 \%$ in the basin was 250 ha. $x_{6} \leq 250$.

1. Riparian forest area constraint, $k=12$. The three-zone buffer strip included $6 \mathrm{~m}$ of forest, which totalled 99 ha, the maximum necessary to protect the riverbanks from meander-type erosion. $x_{9} \leq 99$.

m. Gully floor forestation area constraint, $k=13$. The maximum area to the gully forest was $143 \mathrm{ha}$, estimated by the total gully surface area in map view. $x_{10} \leq 143$. 
Table 1. Technical Equations matrix $\mathbf{T E}_{i j}=a_{i j}$ for La Colacha basin.

\begin{tabular}{|c|c|c|c|c|c|c|c|c|}
\hline \multirow{3}{*}{$i \downarrow$} & \multirow{3}{*}{ Decision variable $\downarrow$} & \multicolumn{6}{|c|}{ Evaluation criteria (units explained in text) } & \multirow{3}{*}{$\begin{array}{r}\text { EMP } \\
6\end{array}$} \\
\hline & & & PRU & ERO & SED & INV & BEN & \\
\hline & & $j=$ & 1 & 2 & 3 & 4 & 5 & \\
\hline 1 & Corn without SC (ha) & & 11 & 3.36 & 0.33 & - & 1000 & 0.01 \\
\hline 2 & Corn with SC (ha) & & 9 & 1.23 & 0.12 & 27 & 1100 & 0.01 \\
\hline 3 & Soybean without SC (ha) & & 14 & 7.84 & 0.78 & - & 1400 & 0.01 \\
\hline 4 & Soybean with SC (ha) & & 11 & 1.82 & 0.18 & 27 & 1500 & 0.01 \\
\hline 5 & Pasture for cattle (ha) & & 8 & 0.98 & 0.09 & 106 & 365 & 0.02 \\
\hline 6 & Grass buffer strip (ha) & & 8 & 0.98 & -3.0 & 106 & 365 & 0.02 \\
\hline 7 & Grassed waterways (ha) & & 8 & 1.0 & -3.0 & 106 & 365 & 0.02 \\
\hline 8 & Agro-forestry (ha) & & 6 & 0.3 & 0.02 & 323 & - & 0.075 \\
\hline 9 & Forest buffer strip (ha) & & 6 & 0.2 & - & 323 & - & 0.075 \\
\hline 10 & Gully floor forested (ha) & & 6 & 0.2 & -1.0 & 323 & - & 0.075 \\
\hline 11 & Regulation ponds $\left(\mathrm{N}^{\circ}\right)$ & & -2612 & - & - & 18062 & - & - \\
\hline 12 & Act. gullies head-cut $\left(\mathrm{N}^{\circ}\right)$ & & - & 1454 & 150 & - & - & - \\
\hline 13 & Ctrl. gullies head-cut $\left(\mathrm{N}^{\circ}\right)$ & & - & -128 & -3.0 & 2408 & - & - \\
\hline
\end{tabular}

n. Forest-pastoral (alley pasture) area constraint, $k=14$. This was arbitrarily set to a maximum forest area of $18 \%$ of the agricultural lands to simulate a soil use of $18 \%$ forest, $20 \%$ pasture and $52 \%$ agriculture. This was a simulated soil-use distribution in a hypothetical agro-forestry crop production system. $x_{8} \leq 6152$.

o. Rotation constraint or maximum soybean area, $k=15$. A 4:1 soybean-to-corn ratio was set as the maximum soybean soil-use, which represents the current trend of soil-use intensification in the remainder of the Pampean region. $x_{3}+x_{4} \leq 22345$.

p. Minimum agricultural area constraint, $k=16$. This was set to the equivalent of $52 \%$ of the total agricultural area. $x_{1}+x_{2}+x_{3}+x_{4} \geq 17808$.

q. Minimum pasture area constraint, $k=17$. Considering the actual non-arable lands (riverbanks, dunes and farmers' houses), this was estimated as $13 \%$ of the total agricultural basin area. $x_{5}+x_{6}+x_{7}+x_{8}+x_{9} \geq 4451$.

r. Non-use area constraint, $k=18$. All basin surfaces were required to be in use. This constraint was included in order to obtain solutions with no "empty" areas; it was set to 34000 ha to allow some calculation flexibility and to provide minimal inconsistency in the calculations of the total surface with different soil uses.

$x_{1}+x_{2}+x_{3}+x_{4}+x_{5}+x_{7} \geq 34000$.

\subsection{Pay-off matrix (PM) for La Colacha, ideal and anti-ideal values}

With the precedent assumptions to define P-solutions, to set a LP of form as in (1) some ideal and maybe some anti-ideal values are required in many of the GP methods, especially to set the $g b_{j}$ in (1a), and they were obtained calculating the pay-off matrix, indicated in Table 2 as $\left(\mathbf{P M}_{j^{\prime} j}\right)$ square matrix of order 6 . For each $j^{\prime}$ of $\left(j^{\prime}=1, \ldots, 6\right)$ the best obtainable value in GP for the $\mathrm{CV} v b_{j^{\prime}}$ is reached by optimising it in line (1a) of a LP form of type (1), getting a LP form as in (2) that will give six $v b_{j}$ in results that are copied as $\mathbf{P M}_{j^{\prime} j}=v b_{j}$; and from them getting the GP best $v b_{j^{\prime}}$ for $j=j^{\prime}$. A Pay-off matrix PM is hence obtained, indicated in Table 2, with the best GP obtainable value for each $j^{\prime}, v b_{j^{\prime}}=\mathbf{P M}_{j^{\prime} j^{\prime}}$, in its diagonal, which is called the $j^{\prime}$-ideal value $i d b_{j^{\prime}}$ for the CV of index $j^{\prime}$. Each column $j$ of $\mathbf{P M}$ contains six values $\mathbf{P M}_{j^{\prime} j}$ for the single criteria $j$ in such special optimisations, and the worse one, observed for file $j^{\prime}=j^{\prime \prime}$, is taken as anti-ideal value $a d b_{j}=\mathbf{P M}_{j^{\prime \prime} j}$ for the CV of index $j$ (see Table 2). For each of these six LP of form (2), optimising the $j^{\prime}$ goal or criteria value $v b_{j^{\prime}}$, Table 3 indicates in each column the values obtained for the $13 \mathrm{CV} x_{i}$, left blank if they are 0 .

In (2a), Min or Max will be Max if the $j^{\prime}$-criteria of "more is better type", Min if of "more is worse type"; and in (2c) and $(2 \mathrm{~d}),\left(j, j^{\prime}=1, \ldots ., 6\right)$ and $(i=1, \ldots ., 13)$,

For each $j^{\prime}$ :

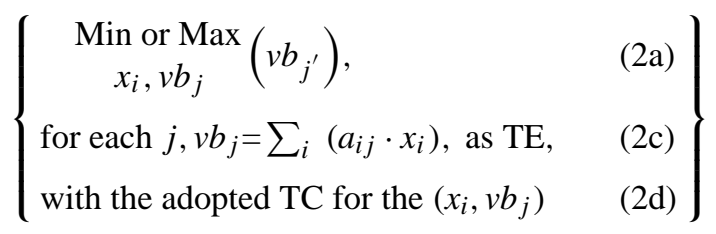

Note in Table 2 that when minimizing the investments (INV), especially those that intervene in SC and in HM, the 
environmental variables (PRU, ERO, SED) get bad values because without SC and HM the flows, erosions and sedimentation will keep known very high values, indicating deterioration of La Colacha area each year. Employment EMP then becomes as worse in $\mathbf{P M}$ at the minimum value imposed in constraints TC. Benefits (BEN) could be optimised by producing maximum valuable crops, at least in the first series of years that have weight in BEN, due mainly to higher surfaces used to produce crops and none for SC. But then in the long term the production capacity would be successively reduced by accumulation of negataive environmental effects destroying part of the agro surface, which is clearly a really bad policy.

\subsection{Use of the GP continuous MCDM for La Colacha area}

\subsubsection{P-solutions for La Colacha obtained by GP optimisations in some scenarios}

With the precedent assumptions the authors in a campaign of trials defined recommended P-solutions for La Colacha area, good in the sense that some characteristics were optimised or kept good in a given GP scenario. The precedent definition of P-solutions was set following expert considerations about the effects of use of soils on reality, including the acceptation by farmers. In each GP scenario a LP of forms as in (1) was set and solved to get a P-solution, and some of these solutions are indicated in Tables 4 and 5 by their obtained $\mathrm{CV}$ variables.

Table 4 contains columns with values of the 13 decision variables DV that describe the recommended use of soil by the measure of surfaces used for each crop or the number of works to be done, and each column corresponds to an scenario corresponding to the GP method used (WGP, LGP, and two to CP) to obtain it, and a last fifth column was filled with averages of non null elements from the precedent columns. The soybean and the corn appear important in solutions with different proportions between them, but with SC for both, almost absolutely in Table 4 scenarios.

\subsubsection{Weighted Goal Programming (WGP) methods}

For WGP each LP has a form following (1), which contains optimisation items as indicated in (1a) and (1b). The weights, which in general are normalised so as to add 1 , assess different relative importance to the deviations from goals of the CV. All the GP used by the authors adopt some WGP forms, and with them at first the authors did general trials.

From them, column 1 of Table 4, labeled as Scenario 4, contains the $13 \mathrm{CV}$ values obtained with a WGP method. For it the adopted weights $w_{j}$ were 0.66 for INV and 0.066 for the other criteria variables. In this WGP the goals as $\{182,29231,1485,385000,9278275,491\}$ at near the $t=90 \%$ level from Anti-ideal to Ideal values, defined using $\left(g b_{j}=a d b_{j}+t \cdot\left(i d b_{j}-a d b_{j}\right)\right)$, except for INV for which $t$ was taken at $50 \%$, and for the denominators in (1a) the rule $r b_{j}=g b_{j}$ was adopted.

Other "iterative" solutions with other weights and goals were found to require much lower surface with soybean and will be not accepted by farmers. These scenario results were analysed in the actual decision-maker context, simulating a participatory process as in Nidumolu et al. (2007). This approach was done for the basin agricultural area, excluding mountainous areas. It was found that this multi-criteria method is not efficient for the inclusion of agro-forestry and does not provide an adequate approach to locate forests, and for that other land-capability objective approaches should be used for this purpose as in Santé Riveira et al. (2008). The authors had obtained some results for that with discrete MCDM.

In relation to the economic indicators that assess the viability of agro-forestry projects, the NPV (net present value) or IRR (internal rate of return) can be complementary as in Hajkowicz (2008). These extensions would require valuation of criteria in monetary units as USD, and effects at long term may be underestimated, as those in PRU, ERO, SED, including degradation of lands by gullies erosion. But this may usefully consider limits in annual budgets for investments, private and public, maybe also in optimisations, and avoid some non-profitable solutions initially too expensive.

\subsubsection{Lexicographic goal programming (LGP) methods}

Following Romero (1989, 1993), in this LGP approach a group of higher priority goals is satisfied first and their CV are determined and then fixed, and the remaining goals are then addressed in groups in a defined priority order. In their research the authors used six successive groups, each one with a single $\mathrm{CV}$ goal, and the aspiration levels were used similarly as for the WGP, with goals $g b_{j}$ and weights $w_{j}$. In each scenario, six LP from a form derived from (1) were successively used, optimising successively in each step only the deviations $\left(p_{j}, n_{j}\right)$ from its known $j$-goal $g b_{j}$ of a single CV $v b_{j}$ for the single corresponding $j$, and fixing the obtained values of $\left(p_{j}, n_{j}\right)$, and hence its $\mathrm{CV} v b_{j}$ from its (1b) $v b_{j}+n_{j}-p_{j}=g b_{j}$, for the following optimisations. In the prior steps the deviations tend to get the value 0 . Three scenarios with variable lexicographic orders were assessed, considering the pay-off matrix results and the constraints implicit in its analysis:

- Scenario 1. Order: 1st BEN $\rightarrow$ 2nd PRU $\rightarrow$ 3rd INV $\rightarrow$ 4th EMP $\rightarrow$ 5th ERO $\rightarrow$ 6th SED

- Scenario 2. Order: 1st ERO $\rightarrow$ 2nd BEN $\rightarrow$ 3rd EMP $\rightarrow$ 4th SED $\rightarrow$ 5th PRU $\rightarrow$ 6th INV

- Scenario 3. Order: 1st BEN $\rightarrow$ 2nd EMP $\rightarrow$ 3rd ERO $\rightarrow$ 4th $\mathrm{SED} \rightarrow$ 5th PRU $\rightarrow$ 6th INV 
Table 2. Pay-off matrix PM or for the criteria of the La Colacha case study. To obtain each $j^{\prime}$-line, the CV $v b_{j^{\prime}}$ was optimised, getting values. In diagonal, in bold, best $j$-ideal values; in $j$-column, in italic, worse $j$-anti-ideal value.

\begin{tabular}{|c|c|c|c|c|c|c|c|}
\hline \multirow[t]{2}{*}{ Optimisation } & \multirow[t]{2}{*}{ for $\downarrow j^{\prime}$} & \multicolumn{2}{|c|}{ In bold, ideal values } & \multicolumn{2}{|c|}{$\leftarrow j$-Criteria, from $(14) \rightarrow$} & \multicolumn{2}{|c|}{ In italics, anti-ideal values } \\
\hline & & $\operatorname{PRU}\left(\mathrm{m}^{3} \mathrm{~s}^{-1}\right)$ & $\operatorname{ERO}\left(\mathrm{Mg} \mathrm{y}^{-1}\right)$ & $\operatorname{SED}\left(\mathrm{Mg}^{-1}\right)$ & INV (US $\left.\$ \mathrm{y}^{-1}\right)$ & BEN (US $\left.\$ \mathrm{y}^{-1}\right)$ & $\operatorname{EMP}\left(\mathrm{N}^{\circ}\right)$ \\
\hline Min PRU & 1 & 165 & 67510 & 6221 & 810556 & 6510097 & 496 \\
\hline Min ERO & 2 & 232 & 26574 & 2261 & 716264 & 6528815 & 500 \\
\hline Min SED & 3 & 291 & 26676 & 1350 & 635777 & 6533495 & 519 \\
\hline Min INV & 4 & 430 & 204362 & 20020 & 170371 & 10336312 & 387 \\
\hline Max BEN & 5 & 348 & 43029 & 3216 & 380724 & 11102209 & 387 \\
\hline Max EMP & 6 & 290 & 26401 & 2236 & 662389 & 6491379 & 545 \\
\hline
\end{tabular}

Table 3. Values of the DV by optimising the $\mathrm{CV} j^{\prime}$ with GP to get the pay-off matrix PM. Column $j^{\prime}$ contains the DV, and the CV are in the $j^{\prime}$ file of matrix PM in Table 2. Values that are 0 are indicated with a blank.

\begin{tabular}{|c|c|c|c|c|c|c|c|}
\hline \multirow{2}{*}{ Decision variable $x_{i}$} & \multirow{2}{*}{$i^{\prime} \downarrow$} & \multicolumn{6}{|c|}{$j^{\prime}$-Criteria for optimization to get the $x_{i}, j$ '-columns } \\
\hline & & Min PRU & Min ERO & Min SED & Min INV & Max BEN & Max EMP \\
\hline Corn without SC (ha) & 1 & & & & 7404 & & \\
\hline Corn with SC (ha) & 2 & 17808 & 17808 & 17808 & & 7415 & 17808 \\
\hline Soybean without SC (ha) & 3 & & & & 22345 & & \\
\hline Soybean with SC (ha) & 4 & & & & & 22345 & \\
\hline Pasture for cattle (ha) & 5 & 15548 & 15748 & 15548 & 4107 & 3857 & 15348 \\
\hline Grass buffer strips (ha) & 6 & & & 250 & & 250 & \\
\hline Grassed waterways & 7 & 344 & 344 & 344 & 344 & 344 & 344 \\
\hline Agro-forestry (ha) & 8 & & & & & & 711 \\
\hline Forest buffer strip (ha) & 9 & & & 99 & & & \\
\hline Gully floor forested (ha) & 10 & & & 143 & & & \\
\hline Regulation ponds $\left(\mathrm{N}^{\circ}\right)$ & 11 & 47 & 22 & 1 & & & \\
\hline Act. gullies head-cut $\left(\mathrm{N}^{\circ}\right)$ & 12 & 26 & & & 7 & & \\
\hline Ctrl. gullies head-cut $\left(\mathrm{N}^{\circ}\right)$ & 13 & 61 & 87 & 87 & 80 & 87 & 87 \\
\hline
\end{tabular}

In scenarios 1 and 3, the farmer's economic interest was prioritised first, whereas in scenario 2, an environmental criterion was optimised first. In scenarios 2 and 3, the INV criterion was optimised ultimately ex professo to avoid a "bottleneck" constraint, and these scenarios could assess the level of investment required and the corresponding achievement level for the other goals. In Table 4 the column LGP (Scenario 3) indicates results for scenario 3.

\subsection{Use of the compromise programming (CP)}

The resolution of CP (see Zeleny, 1982; Romero; 1989, 1993) consisted of obtaining a minimum distance in the $\mathrm{CV}$ space to an ideal point for all the criteria together. This point is defined by the $n$ ideal values $i d b_{j}$, with $n=6$ for the research in this paper. The distance concept in MCDM methods is a surrogate of human preferences. Three typical Minkowsky distance functions or $p$-metrics were used, $p=1, p=2$ and $p=\infty$, from the admissible with $p \geq 1$, and different scenarios were performed varying preferences in the criteria assessed by the values of the assigned weights simulating decision-maker preferences. For this the schema (1) is used, without (1b), and optimising instead of (1a) a $p$-distance to the ideal point in the CV space of form

$\operatorname{Min}_{x x_{i}, v b_{j}}\left(\Sigma_{j}\left|\frac{\left(v b_{j}-i d b_{j}\right) \cdot w_{j}}{\left(i d b_{j}-a d b_{j}\right)}\right|^{p}\right)^{1 / p}$.

This distance was mostly used for $p=1$ and $p=2$, as usual, and also for $p=\infty$ assuming that then it is

$\operatorname{Min}_{x x_{i}, v b_{j}}\left(\operatorname{Sup}_{j}\left|\frac{\left(v b_{j}-i d b_{j}\right) \cdot w_{j}}{\left(i d b_{j}-a d b_{j}\right)}\right|\right)$.

In the research trials nine scenarios were made, taking for them three weights distributions, one with equal weights, a second with greater weight in ERO, and the third with greater weight in PRU. For each distribution three values of $p$ were considered, $p=1, p=2$ and $p=\infty$. The results are indicated with their obtained DV in Table 5. The values 1 and 2 
Table 4. Four feasible solutions for different GP MCDM for La Colacha basin.

\begin{tabular}{|c|c|c|c|c|c|}
\hline Decision Variable & WGP & LGP & $\mathrm{CP}$ & $\mathrm{CP}$ & \multirow[t]{2}{*}{ Average } \\
\hline Scenario & 4 & 3 & 2 & 5 & \\
\hline Corn without SC (ha) & & 810 & & & 810 \\
\hline Corn with SC (ha) & 16916 & 5667 & 6945 & 11542 & 10268 \\
\hline \multicolumn{6}{|l|}{ Soybean without SC (ha) } \\
\hline Soybean with SC (ha) & 12525 & 19759 & 22345 & 16884 & 17878 \\
\hline Pasture for cattle (ha) & 3714 & 5918 & 3865 & 4729 & 4557 \\
\hline Grass buffer strip (ha) & 250 & & 98 & & 174 \\
\hline Grassed waterways (ha) & 344 & 344 & 344 & 344 & 344 \\
\hline Agro-forestry (ha) & & 1003 & & 407 & 705 \\
\hline Forest buffer strip (ha) & & 99 & & & 99 \\
\hline Gully floor forested (ha) & 143 & 143 & 143 & 143 & 143 \\
\hline Regulation ponds $\left(\mathrm{N}^{\circ}\right)$ & 32 & 47 & 47 & 16 & 36 \\
\hline \multicolumn{6}{|l|}{ Act. gullies head-cut $\left(\mathrm{N}^{\circ}\right)$} \\
\hline Ctrl. gullies head-cut $\left(\mathrm{N}^{\circ}\right)$ & 87 & 87 & 87 & 87 & 87 \\
\hline
\end{tabular}

Table 5. Results from CP of nine scenarios for the DV in La Colacha.

\begin{tabular}{|c|c|c|c|c|c|c|c|c|c|}
\hline \multirow[t]{2}{*}{ Decision Variables } & \multicolumn{9}{|c|}{ Case study - Scenarios } \\
\hline & Scen.1 & Scen. 2 & Scen. 3 & Scen. 4 & Scen. 5 & Scen.6 & Scen.7 & Scen.8 & Scen.9 \\
\hline Metric : & \multicolumn{3}{|c|}{$p=1$} & \multicolumn{3}{|c|}{$p=2$} & \multicolumn{3}{|c|}{$p=\infty$} \\
\hline Weight in & - & ERO & PRU & - & ERO & PRU & - & ERO & PRU \\
\hline Corn without SC (ha) & & & & & & 6120 & & 394 & 28742 \\
\hline Corn with SC (ha) & 7415 & 6945 & 29220 & 1727 & 11542 & 20932 & 13239 & 23957 & 365 \\
\hline Soybean without SC (ha) & & & & & & & 11469 & 5222 & \\
\hline Soybean with SC (ha) & 22345 & 22345 & & 22345 & 16884 & 2433 & 0.5 & & \\
\hline Pasture for cattle (ha) & 3395 & 3865 & 3865 & 9083 & 4729 & 3659 & 8447 & 4118 & 4392 \\
\hline Grass buffer strip (ha) & & 98 & 98 & & & & & & \\
\hline Grassed waterways (ha) & 344 & 344 & 344 & 344 & 344 & 344 & 344 & & \\
\hline Agro-forestry (ha) & 469 & & & 377 & 407 & 205 & 269 & 90 & \\
\hline Forest buffer strip (ha) & 99 & & & 99 & & 99 & 99 & 99 & 58 \\
\hline Gully floor forested (ha) & 143 & 143 & 143 & 143 & 143 & 143 & 143 & 143 & \\
\hline Regulation ponds $\left(\mathrm{N}^{\circ}\right)$ & & 47 & 47 & 9 & 16 & 26 & 19 & 19 & 47 \\
\hline Active gullies $\left(\mathrm{N}^{\circ}\right)$ & & & & & & & 9 & & 19 \\
\hline Controlled gullies $\left(\mathrm{N}^{\circ}\right)$ & 87 & 87 & 87 & 87 & 87 & 87 & 78 & 87 & 68 \\
\hline
\end{tabular}

were found the best for $p$. The CP was found good to consider environment variables, as in fact it makes a balance between the effects of them. In Table 4 the results for the CP methods are in two columns (CP, Scenario 2 and Scenario 5), for two scenarios with good results designed in view of the precedents.

All the scenarios showed with the GP methods very different crop rotation efficient points, from an SC-based soybean almost monoculture to corn monoculture without SC adoption, which was discarded as it probably would be rejected by both farmers and environmentalists (low BEN, SED and ERO goal achievement). In relation to the HM, the solutions consistently demonstrate that gully head-cut control, gully floor forestation, ponds and grassed waterways should be present in all HM plans. Forest buffer strips, and especially grass strips as SC, had only a minor presence in the solutions. In short, a similar trend was shown in the WGP and LGP best alternatives, with soybean-corn ratios of $3: 1$ or $1: 1$. The viable options remaining showed variable levels of criterion achievement, with similar results, and a combination of these options probably provides the optimal solution. It remains to be resolved the finding of an optimum number of ponds, a project that requires intensive investment, as the number fluctuates much, being 16 for scenario 5 and a 47 for scenario 2, see Table 5. 


\section{Results and discussion of continuous methods}

It can be seen globally that the continuous MCMD offers a tool to define valid P-solutions for La Colacha, and to select optimum P-solutions by LP in various scenarios for GP, aiming to find policies in the crops and in the measures to conserve the La Colacha study area. Such best solutions depend on hypotheses and on the GP model used by analysts. So the authors have obtained methods of interactive analysis that they think conform to realities and therefore may be an aid to set and evaluate coherent solutions in planning.

Some relevant combined consequences are observed. The ideal points (Table 2) show the conflict level in relation to the environmental, economic and social criteria used. The optimal values of the environmental criteria (PRU, ERO and SED) matched the worst values for the economic criteria, especially for INV and, to a lesser extent, for BEN. The ideal values of the two economic variables INV and BEN had the least conflict, because the increases in INV are assumed to be in high part for works to avoid erosion by SC and HM. The value for BEN obtained at the ideal point of INV was quite similar to the BEN maximum. Among the economic criteria, BEN was more compatible with a better environmental condition than was INV; that is, optimisation of BEN generated minor environmental degradation compared to INV optimisation. In the same sense, the conflict between the environmental and social criteria was minimal.

Diverse real policies could be made in the future for these areas, and they will depend on the demand and prices of products. Pasture will be limited as from Table 5 results, Grassed waterway will be much recommended, and Grass buffer strip and Forest buffer strip much less. Agro-forestry may be increased slightly, which was discussed between scenarios. In any case, the gullies must be better controlled than now in a general effort to reduce the high actual level of erosion. This conclusion resulted for all scenarios, as is visible in Table 4. As other results from Table 5 mainly, alternatives that minimize the PRU and ERO were consistent with a basin HM design fully developed with grassed waterways, regulation ponds and gully control, whereas the SED optimal management incorporated buffer grasses and river and gully forests. The unique alternative that considers some minimum agro-forestry areas is the optimisation of the EMP criterion, clearly demonstrating the employment generation of this activity, although it was suboptimal for the remaining criteria. In normative terms, the data assessment suggests that optimal solutions should aim to adopt integral SC and HM strategies to solve environmental conflicts that will unfold in medium or long-term economics. The management plan more attractive to farmers and land-renters, in which the BEN was optimised, was SC-based with a 3:1 ratio of soybeans to corn and partial HM works (complete grassed buffers and waterways and head-cut gully control). This efficient alternative appeared as the first approximation of "best" optimised strategy for soil use as tested with continuous multi- criteria methods. The crop rotations are realistic, although they will require an intense SC-adoption policy and an exhaustive analysis of private and public investment-sharing strategy. With a first basic data set, the authors demonstrated that the actual, and probably the future, productive strategy is supported by a rationale of minimizing INV and maximising BEN, a strategy that is obviously market-oriented and based exclusively on private economic criteria (Prato and Herat, 2007); but it is in strong conflict with all environmental and social criteria. The principal real constraints seem to be the INV possibilities and degree and dynamics of farmers' adoption of SC in crop technology. But this SC is necessary to avoid successive erosions that, if not limited by SC and $\mathrm{HM}$, will degrade the area and reduce productions, and hence $\mathrm{BEN}$, and also EPM, for the middle term.

The continuous methods showed the possibility of thorough analysis on the combined effects of the levels of actions related to types of crop, care of environment, and measures for SC and HM. They allow considering combined effects that are poorly apparent otherwise, so it is a valid tool to be incorporated in studies and in planning. But diverse sets of premises are reasonable, and the results are not unique, and they depend especially on the relative importance imposed of each criterion. These methods are hence more a tool to consider consequences on proposed uses of soils of study areas than to fix single optimum decisions. These continuous MCDM are a tool that offers a better view of the consequence of technical and economical external variables on optimum solutions.

\section{Conclusions}

The information and methods indicated in this paper are appropriated as aid for hydro-basin planning. The paper presents extracts of significant research by authors, and indicates the techniques used for La Colacha area with continuous MCDM that offer mostly interactive aiding tools for planning. The results put in evidence the interest of having conservation policies by public and private combined actions, maybe with subventions, to improve the state of the studied basins that are differently degraded. GIS, methods of hydrology and those of soil erosion control were handled in the first steps of research, aiding to provide some general information for this paper. The exposed methods could obtain priorities of actions and of timing. The conservation and amelioration of lands will require actions for SC and for HM, after inspection on the state of plots and soil water content.

These continuous MCDM required a set or block of combined definitions, of a DVS to define tuning of solutions, of functions to qualify them in multi-criteria forms using a CVS, and of constraints naturally imposed or elicited to achieve correct solutions defined with CE. For these, various GP methods were used with relative simple LP methods but requiring tuned scenarios in setting a variety of 
optimisations, and with them finer conclusions. The results recommend modest variations on actual use, but emphasize soils conservation (SC) practices and hydraulic management (HM) works to conserve the high quality of the surface of soils that can be easily spoiled without them in a matter of some decades.

In the research an ample inspection on the state of art of DSS models for such planning was effectuated, and part of it is indicated in the references. The results in this paper are being used in a regional planning project promoted by public entities in Argentina, aiming at rural planning. The ways to do them, how to pay for them by land owners or by public agencies, and the legal ways to get them progressively enacted in the following years or decades will be a new source of studies that could be aided with extension of the continuous MCDM presented in this paper.

Acknowledgements. This study was performed with funds from the UPM in a "Proyecto Semilla 2009" between the UPM and the National University of Río Cuarto (UNRC), from a research project funded by the UNRC, from a doctoral fellowship supported by the Carolina Foundation and by the Ministry of Science, Technology and Productive Innovation of the Argentine Republic. It was partially support by CICYT project AGL2006-12689/AGR and AGL2010-21501/AGR. Comunidad de Madrid contributed through projects CCG07-UPM/000-1995 and CG07-UPM/AMB-1998.

Edited by: A. M. Tarquis

Reviewed by: two anonymous referees

\section{References}

Agrell, P. J., Stam, A., and Fischer, G. W.: Interactive multiobjective agro-ecological land use planning: The Bungoma region in Kenya, Eur. J. Oper. Res., 158, 194-217, 2004.

Anton, J. M., Grau, J. B., Tarquis, A. M., and Sanchez D. C.: MCDM Methods for Territorial Services Planning in an Andine rural area, WAC 2006, Budapest, Hungary, 24-27 July 2006, IISSCI_13, 5, TSI Press, San Antonio TX (Texas), USA, 2006.

Anton, J. M., Grau, J. B., Tarquis, A. M., Cisneros, J. M., and Andina, D.: Decision theories used in planning of areas around La Colacha basin in Córdoba (Argentine) considering natural and human hazards, Geophys. Res. Abstr., 12, EGU2010-14849, 2010.

Borin, M., Passoni, M., Thiene, M., and Tempesta, T.: Multiple functions of buffer strips in farming areas, Eur. J. Agron., 32, 103-111, 2010.

Brierkley, G. J. and Fryirs, K. A.: Geomorphology and river management. Applications of the river styles, Framework. Blackwell Publishing, Oxford, UK, 398 pp., 2005.

Bryan, B. A. and Crossman, N. D.: Systematic regional planning for multiple objective natural resources management, J. Environ. Manage., 88, 1175-1189, 2008.

Cantero, A., Bricchi, E., Becerra, V. H., Cisneros, J. M., and Gil, H.: Zonificación y descripción de las tierras del Departamento Río Cuarto (Córdoba), Ed. UNRC, Rio Cuarto, Argentina, 80 pp., 1986.
Cantero, G., A., Cantú, M., Cisneros, J. M., Cantero, J. J. Blarasin, M., Degioanni, A., Gonzalez, J., Becerra, V., Gil, H., De Prada, J., Degiovanni, S., Cholaky, C., Villegas, M., Cabrera, A., and Eric, C.: Las tierras y aguas del sur de Córdoba. Propuestas para un manejo sustentable, Ed. UNRC, Argentina, 119 pp., 1998.

Chang, N.-B., Wen, C. G., and Wu, S. L.: Optimal management of environmental and land resources in a reservoir watershed by multi-objective programming, J. Environ. Manage., 44, 145-161, 1995.

Cisneros, J. M., Cantero, G. A., González, J., De Prada, J., Reynero, Ma. Gil, H., Degioanni, A., Cholaky, C., Becerra, V. H., and Mongi, F.: Identificación de los focos activos de erosión hídrica lineal y programa de control de erosión en la cuenca media y alta del arroyo Santa Catalina (arroyos La Barranquita, Cipión y La Colacha), Informe Final Protocolo Específico de Cooperación Dirección Provincial de Agua y Saneamiento, edited by: (DIPAS) - UNRC/FAV. 20 pp, y anexos (catálogo de prácticas y cartográfico), 2005.

Cisneros, J. M., Cantero, A., Degioanni, A., Becerra, V. H., and Zubrzycki M. A.: Producción, Uso y Manejo de las Tierras, in: Percepción económica y visión de los productores agropecuarios de los problemas ambientales en el Sur de Córdoba, edited by: de Prada J. D. and Penna, J., Instituto de Economía y Sociología INTA, Argentina, 57-73, 2008a.

Cisneros, J. M., Cantero G. A., Degioanni, A., Angeli, A., González, J. G., De Prada, J. D., Reynero, M. A., Gil, H. A., Becerra, V. H., and Espósito, G.: Uso del suelo, erosión y deterioro de caminos rurales: el caso de la cuenca Suco-Moldes-Mackenna (Cordoba), in: XXI Congreso Argentino de la Ciencia del Suelo. Potrero de los Funes (San Luis), 13-16 May 2008b.

Cisneros, J. M., Grau, J. B., Antón, J. M., de Prada, J. D., Cantero, A., and Degioanni, A. J.: Assessing multi-criteria approaches with environmental, economic and social attributes, weights, procedures: A case study in the Pampas, Argentina, Agri. Water Manage., 98, 1545-1556, 2011.

Cristeche, E. R.: Valoración económica de los efectos externos de la erosión hídrica sobre la infraestructura de caminos rurales en el Sur de la provincia de Córdoba, Argentina, Ph.D. thesis, Facultad de Ciencias Económicas, Universidad de Buenos Aires, 2009.

Dabney, S. M., Yoder, D. C., Bingner, R. L., and Vieira, D. A. N.: Predicting runoff for a RUSLE2 ephemeral gully calculator, in: tucson.ars.ag.gov/isco/isco15/pdf/DabneyS PredictingrunoffforaRUSLE2.pdf, 2008.

De Prada, J. D., Boretto, J., Ferrando, M., Garcia, A., Olmos, J., and Marcelo S.: Proyecto de conservación y ordenamiento de tierras General Deheza. Master of Art, Universidad Nacional de Córdoba, Córdoba, 1994.

De Prada, J. D., Lee, T. S., Angeli, A. R., Cisneros, J. M., Cantero, G., and Cantero, A.: Análisis multicriterio de la conservación de suelo: Aplicación a una cuenca representativa del centro Argentino. Revista Iberoamericana de Economía Ecológica, 9, 4559, http://www.redibec.org/IVO/rev9_04.pdf, 2008.

De Prada, J. D. and Penna, J.: Percepción económica y visión de los productores agropecuarios de los problemas ambientales en el sur de Córdoba, Argentina. Estudios socioeconómicos de la sustentabilidad de los sistemas de producción y recursos naturales. $\mathrm{N}^{\circ}$ 08, IES INTA, 93 pp., 2009.

Degioanni, A., Camarasa Belmonte, A., and Moreno Sanz, F.: Bases Metodológicas para la Evaluación, Uso y Gestión Sostenible de 
los Recursos Agrarios. Aplicación a la cuenca Santa Catalina (Argentina). In: Tecnologías Geográficas para el Desarrollo Sostenible, Asociación de Geógrafos españoles. Universidad de Alcalá de Henares(Eds.), Madrid, España, 290-311, 2000.

Fiener, P. and Auerswald, K.: Seasonal variation of grassed waterway effectiveness in reducing runoff and sediment delivery from agricultural watersheds in temperate Europe, Soil Tillage Res. 87, 48-58, 2006.

Gassman, P. W. Williams, J. R., Wang, X., Saleh, A., Osei, E., Hauck, L. M., Hauck, R. C., Izaurralde, and Flowers, J. D.: The Agricultural Policy Environmental Extender (APEX) Model: An Emerging Tool for Landscape and Watershed Environmental Analyses, Technical Report 09-TR 49. Center for Agricultural and Rural Development, Iowa State University, Available at: http://www.card.iastate.edu/publications/DBS/PDFFiles/ 09tr49.pdf, 2009.

Gil, H. A., de Prada, J. D., Hernandez, J., Pereyra, C., and Angeli, A. R.: Análisis de la Percepción del Productor sobre la Problemática Ambiental, in: Percepción económica y visión de los productores agropecuarios de los problemas ambientales en el Sur de Córdoba, edited by: de Prada, J. D. and Penna, J., Argentina, Instituto de Economía y Sociología INTA, 94 pp., 2008.

Giupponi, C., Mysiak, J., Fassio, A., and Cogan, V.: MULINODSS: A computer tool for sustainable use of water resources at the catchment scale, Math. Comput. Simulat., 64, 13-24, 2004.

Gonçalvez, J. M., Pereira, L. S., Fang, S. X., and Dong, B.: Modelling and multi-criteria analysis of water saving scenarios for an irrigation district in upper Yellow River Basin, Agr. Water Manage., 94, 93-108, 2007.

Grau, J. B.: Curso: Métodos matemáticos para la toma de decisiones. Escuela de Postgrado de la Facultad de Ciencias Naturales, Universidad Nacional de Salta, Argentina, 2003.

Grau, J., Anton, J. M., and Tarquis, A. M.: MCDM Methods for Waste Management Planning in a rural Area. Proceedings of CITSA 2007, session Soft Computing and Signal Processing, Orlando Florida USA, 15-17 July, 2007.

Grau, J. B., Antón, J. M., Tarquis, A. M., and Andina, D.: Election of water resources management entity using a multi-criteria decision (MCD) method in Salta province (Argentine), Proceedings WMSCI 2008, I, 30-35, Orlando, Florida, USA, 2008.

Grau, J. B., Anton, J. M., Tarquis, A. M., and Andina, D.: Election of water resources management entity using a multi-criteria decision (MCD) method in Salta province (Argentine). Journal of Systemics, Cybernetics and Informatics, 7, 5, 1-7, www. iiisci.org/Journal/SCI/, (First presented in CITSA2008, Orlando, Florida USA), 2009.

Grau, J. B., Antón, J. M., Tarquis, A. M., Colombo, F., de los Ríos, L., and Cisneros, J. M.: An application of mathematical models to select the optimal alternative for an integral plan to desertification and erosion control (Chaco Area - Salta Province - Argentina), Biogeosciences, 7, 3421-3433, doi:10.5194/bg-73421-2010, 2010.

Groot, J. C. J., Rossing, W. A. H, Jellema, A., Stobbelaar, D. J., Renting, H., and Van Ittersum, M. K.: Exploring multi-scale trade-offs between nature conservation, agricultural profits and landscape quality, A Methodology to support discussions on land-use perspectives, Agriculture, Ecosys. Environ., 120, 5869, 2007.
Hajkowicz, S.: Rethinking the economist's evaluation toolkit in light of sustainability policy, Sustainability, Science, Practice and Policy, 4, 17-24, 2008.

Hengsdijk, H. and van Ittersum, M. K.: A goal-oriented approach to identify and engineer land use systems, Agri. Syst., 71, 231-224, 2002.

Janssen, R.: On the use of multi-criteria analysis in environmental impact assessment in The Netherlands, J. Multi-crit. Decis. Anal., 10, 101-109, 2001.

Kenyon, W., Hill, G., and Shannon, P.: Scoping the role of agriculture in sustainable flood management, Land Use Policy, 25, 351-360, 2008.

Lakshminarayan, P. G., Johnson, S. R., and Bouzaher, A.: A multiobjective approach to integrating agricultural economic and environmental policies, J. Environ. Manage., 45, 365-378, 1995.

Lasage, R.: A multi criteria analysis of water management strategies in Kitui, Kenya, Research paper 4 within the WatManSup project. Report W-07/14, Vrije Univesiteit Amsterdam, 2007.

Llach, J., Harriague, M., and O'Connor, E.: La generación de empleo en las cadenas agroindustriales. Ed. Fundación Producir Conservando, Buenos Aires, Argentina, 72 pp., 2004.

Lovell, S. T. and Sullivan, W. C.: Environmental benefits of conservation buffers in the United States: Evidence, promise and open questions, Agr. Ecosyst. Environ., 112, 249-260, 2006.

Manuel-Navarrete, D., Gallopin, G., Blanco, M., Diaz-Zorita, M., Ferraro, D., Herzer, H., Laterra, P., Morello, J., Muráis, M., Pengue, W., Piñeiro, M., Podestá E., Satorre, E., Torrent, M., Torres, F., Viglizzo, E., Caputo, M., and Celis, A.: Análisis sistémico de la agriculturización en la pampa húmeda argentina y sus consecuencias en regiones extrapampeanas: sostenibilidad brechas de conocimiento e integración de políticas. CEPAL, Serie Medio Ambiente y Desarrollo 118, Santiago de Chile, Chile, 2005.

McIntyre, N. R. and Wheater, H. S.: A tool for risk-based management of surface water quality, Environ. Model. Softw., 19, 1131-1140, 2004.

Millennium Ecosystem Assessment: Ecosystems and human wellbeing. Current state and trends findings of the condition and trends working group, Island Press, Washington, DC, 2005.

Morgan, R. P. C. and Rickson, R. J.: Slope stabilization and erosion control: a bioengineering approach, E\&FN Spon, 274 pp., 1995.

Muñoz-Carpena, R. and Parsons, J. E.: VFSMOD-W Vegetative filter strips hydrology and sediment transport modeling system, Model documentation and user manual. Ag. \& Bio. Eng./IFAS, U. of Florida and Bio \& Ag. Engineering-NC State University, available at: abe.ufl.edu/carpena/vfsmod/citations.shtml, 2005.

Nidumolu, U. B., van Keulen, H., Lubbers, M., and Mapfumo, A.: Combining interactive multiple goal linear programming with and inter-stakeholder communication matrix to generate land use options, Environ. Model. Softw., 22, 73-83, 2007.

Paneque Salgado, P., Corral Quintana, S., Guimaraes Pereira, A., del Moral Ituarte, L., and Pedregal Mateos, B.: Participative multi-criteria analysis for the evaluation of water governance alternatives. A case study in the Costa del Sol (Málaga), Ecol. Econom., 68, 990-1005, 2006.

Paruelo, J. M.: Valoración de servicios ecosistémicos y planificación del uso del territorio ¿Es necesario hablar de dinero?, in: Expansión e intensificación agrícola en Argentina: Valoración de bienes y servicios ecosistémicos para el ordenamiento territorial, edited by: Paruelo, J. M., Jobaggy, E. G,. and Laterra, P., 
Ediciones INTA, Argentina, INTA Buenos Aires, 740 pp., 121139, 2011.

Pengue, W. A.: Transgenic Crops in Argentina: The Ecological and Social Debt, Bulletin of Science, Technol. Soc., 25, 4, 314-322, 2005.

Poesen, J., Natchergaele, J., Verstraeten, G., and Valentin, C.: Gully erosion and environmental change: importance and research needs, Catena 50, 91-133, 2003.

Prato, T. and Herath, G.: Multiple-criteria decision analysis for integrated catchment management. Ecol. Model., 63, 627-632, 2007.

Romero, C.: Handbook of Critical Issues in Goal Programming. Pergamon Press, Oxford, 124 pp., 1991.

Romero, C.: Teoría de la decisión multicriterio: Conceptos, técnicas y aplicaciones, Alianza Editorial, Madrid, 195 pp., 1993.

Romero, C. and Rehman, T.: Multiple criteria analysis for agricultural decisions, Elsevier Science Ed., 255 pp., 1989.

Rossing, W. A. H., Zander, P, Josien, E., Groot, J. C. J., Meyer, B. C., and Knierim, A.: Integrative modelling approaches for analysis of impact of multifunctional agriculture: A review for France, Germany and The Netherlands, Agr. Ecosyst. Environ., 120, 4157, 2007.

Santé-Riveira, I., Crecente-Maseda, R., and Miranda-Barrós, D.: GIS-based planning support system for rural land-use allocation. Comput. Electron. Agr., 63, 257-263, 2008.

Simonovic, S. and Akter, T.: Participatory flood plain management in the Red River Basin. Canada, Annu. Rev. Control, 30, 183 192, 2006.

Smith C. S. and McDonald G. T.: Assessing the sustainability of agriculture at the planning stage, J. Environ. Manage., 52, 1537, 1998.
Udawatta, R. J., Krstanky, J. J., Henderson, G. S., and Garrett, H. E.: Agroforestry practices, runoff and nutrient losses: A paired watershed comparison, J. Environ. Qual., 31, 1214-1225, 2002.

Ullrich, A. and Volk, M.: Application of the Soil and Water Assessment Tool (SWAT) to predict the impact of alternative management practices on water quality and quantity, Agr. Water Manage., 96, 1207-1217, 2009.

USACE (US Army Corp of Engineers): HEC-HMS Hydrologic model System, V 3.4, http://www.hec.usace.army.mil/software/ hec-hms, 2009.

USDA-ARS: Science Documentation revised universal soil loss equation, Version 2, http://fargo.nserl.purdue.edu/rusle2, 2009.

Wilkinson, S. N., Prosser, I. P., Rustomji, P. and Read, A. M.: Modelling and testing spatially distributed sediment budgets to relate erosion processes to sediment yields, Environ. Modell. Softw., 24, 489-501, 2009.

Williams, J. R.: Sediment-yield prediction with Universal Equation using runoff energy factor. Present and Prospective Technology for Predicting Sediment Yields and Sources. ARS-S-40, US Department of Agriculture, Agri. Res. Service, 244-252, 1975.

Zack, M. E., Cabido, M., Cáceres, D., and Díaz, S.: What drives accelerated land Cover change in Central Argentina?. Synergistic consequences of climatic, socioeconomic, and technological factors, Environ. Manage., 42, 181-189, 2008.

Zeleny, M.: Multiple criteria decision making. Mc Graw-Hill, New York, 563 pp., 1982.

Zhen, W., Juan, Y. Y., Cheng, G. H. and Zhan, X. Y.: Application of Multi-attribute decision making methods on slope treatment of small watershed, Environ. Informatics Archives, 5, 728-736, 2007. 